\title{
Predatory Journals: How Far Can They Go? An In-Depth Look at the Outliers Grabežljivi časopisi: koliko daleko mogu ići? Temeljita analiza vrijednosti
}

\author{
Alexandru-Ionuţ Petrişor \\ Ion Mincu University of Architecture and Urbanism, Bucharest, Romania \\ alexandru.petrisor@uauim.ro (institutional), alexandru_petrisor@yahoo.com (personal)
}

\section{Article Info / Informacije o članku}

Primljen / Received 17. 2. 2021.

Prihvaćen / Accepted 18. 5. 2021.

Dostupan online / Available online: 1. 12. 2021.

\section{Keywords / Ključne riječi}

predatory publishers, spam, fake science, language use, boosting language, deceptive language

grabežljivi izdavači, neželjena pošta, lažna nauka upotreba jezika, poticanje jezika, obmanjujući jezik

\begin{abstract}
Sažetak
For over a decade, predatory publishers, journals and conferences have continuously menaced the research community, preying on its resources, and diminishing the general trust in science, becoming an important research topic. Previous studies have focused on identifying their characteristics, in order to increase the academic awareness and help researchers not becoming a prey. At the same time, predatory publishers diversified their strategies; the academic community developed disparate reactions, which determined more and diverse predatory strategies, aimed at luring and deceiving the scientists. While the process is still ongoing, the present research is aimed at exposing the most extreme predation strategies, in an effort to make the line separating honest and predatory journals more traceable. The analysis of relevant samples focuses on the language issue, based on the hypothesis according to which the predatory publishers are located in countries where English is rarely spoken. The findings, including inventing English names, advertisements making no sense for the Western world, lack of quality control and a poor graphic language, confirm the hypothesis, and are also able to stand at the core of possible guidelines for exposing predatory publishers based on specific features of their calls.
\end{abstract}

Više od deset godina, grabežljivi izdavači, časopisi i konferencije kontinuirano su ugrožavali istraživačku zajednicu, loveći njene resurse i umanjujući opće povjerenje u nauku, postajući važna istraživačka tema. Prethodne studije bile su usredotočene na identificiranje njihovih karakteristika, kako bi se povećala akademska svijest i pomoglo istraživačima da ne postanu plijen. Istodobno, grabežljivi izdavači diverzificirali su svoje strategije; akademska zajednica razvila je različite reakcije, koje su odredile više i raznovrsnije predatorske strategije, usmjerene na mamljenje i obmanjivanje naučnika. lako je postupak još uvijek u toku, ovo je istraživanje usmjereno na izlaganje najekstremnijih strategija grabežljivosti, nastojeći da linija koja razdvaja poštene i grabežljive časopise postane sljedivija. Analiza relevantnih studija slučaja usredotočena je na jezičko pitanje, zasnovano na hipotezi prema kojoj se izdavači nalaze u zemljama u kojima se engleski jezik rijetko govori. Nalazi, uključujući izmišljanje engleskih imena, reklame koje nemaju smisla za zapadni svijet, nedostatak kontrole kvaliteta i loš grafički jezik, potvrđuju hipotezu i takođe mogu stajati u srži mogućih smjernica za izlaganje predatorskih izdavača na osnovu specifičnih karakteristika njihovih poziva.

\section{Introduction}

Probably most researchers who have published an article which became available online, or attended a conference that displayed online its program, received, sooner or later, a call for paper advertising a journal eager to publish a similar article to the one already published, or an article based on the conference presentations. Most such calls proved to be sent by the "predatory journals", a term attributed to the United States based academic librarian and researcher Jeffrey Beall, who coined it in 2008 (Butler 2013). Beall is the author of a blacklist, now removed and even disputed (Teixeira da Silva 2017),

\section{Uvod}

Vjerovatno je većina istraživača koji su objavili članak koji je postao dostupan na mreži ili su prisustvovali konferenciji koja je predstavila svoj program na mreži, prije ili kasnije dobili poziv za rad u reklamiranom časopisu koji želi da objavi članak sličan onom objavljenom ili članak koji se zasniva na prezentaciji s konferencije. Za većinu takvih poziva je dokazano da su ih poslali "grabežljivi časopisi" - pojam se pripisuje akademskom bibliotekaru $\mathrm{i}$ istraživaču sa sjedištem u Sjedinjenim Državama, Jeffreyju Beallu, koji ga je skovao 2008. godine (Butler 2013). Beall je autor crne liste, sada uklo- 
which listed predatory publishers and journals, a distinction made from the very beginning. Later on, the "predatory" concept was extended over the conferences too. Although everyone used the concept, it lacked a definition until 2019, when it was reached by consensus: "entities that prioritize self-interest at the expense of scholarship and are characterized by false or misleading information, deviation from best editorial and publication practices, a lack of transparency, and/or the use of aggressive and indiscriminate solicitation practices" (Grudniewicz et al. 2019).

Provided that predatory publishers corrupt and exploit the principles of 'open access' (Dizdar 2019), the consequence of some calls can prove, especially for the researchers in the beginning of their career disastrous; the possible outcomes include, most frequently, deception (Alnajjar et al. 2020), loss of money (Moher et al. 2019), loss of time to get the article withdrawn (Chambers 2019), distrust in science (Habibzadeh and Simundic 2017). However, for those who have acquired sufficient experience, the situation differs. Some are annoyed, others do no longer react. Personally, I have found a moral duty to systematically read such calls between the lines, and finding trends and elements that translate into articles, aimed first of all at warning other researchers of the danger hiding behind such calls (Petrişor 2016, 2017, 2018).

The goal of this study is to bring more evidence that the predatory publishers are based in countries that do not observe the established Western research standards, and they have no scientific grounds, do not adhere to the research and even general ethics, and have absolutely no limits in pursuing their goal of making money by deceiving their potential victims, as the title of the article suggests.

\section{Data and methods}

Several studies have addressed English language related issues with respect to the predatory journals. Soler and Cooper (2019) believe that the repeated rejection due to the level of the English proficiency, often used as a 'milder' reason by publishers to reject articles unlikely to receive sufficient citations instead of the 'tougher' lack of research depth (Petrişor 2020), favored the predatory journals, which do not hesitate to accept any submission, regardless of the language level, if the authors pay their fees. For non-native English speakers, the fear of a rejection due do the language level is justified (Kurt 2018). This could become critical in countries in which, according to Ebadi and Zamani (2018), although English is not an official language, promotion and funding criteria require authors to publish articles in English. In this setting, Petrişor (2017) shows that the predatory calls appear to come from njene i čak osporavane (Teixeira da Silva 2017), u kojem su navedeni grabežljivi izdavači i časopisi, među kojima je razlika napravljena na samom početku. Kasnije, "grabežljivi” koncept je također proširen na konferencije. Iako svi koriste koncept, nedostajala je definicija do 2019. godine, kada je postignut konsenzus da su to: "subjekti koji daju prednost vlastitom interesu nauštrb nauci i koje karakteriziraju lažne ili zavaravajuće informacije, odstupanje od najboljih uredničkih i izdavačkih praksi, nedostatak transparentnosti i/ili korištenje agresivnih i neselektivnih praksi prikupljanja podataka" (Grudniewicz et al. 2019).

Pod pretpostavkom da grabežljivi izdavači srozavaju i iskorištavaju načela 'otvorenog pristupa' (Dizdar 2019), posljedica nekih poziva može se pokazati, osobito za istraživače na početku karijere, katastrofalnom; mogući ishodi uključuju, najčešće, prevaru (Alnajjar et al. 2020), gubitak novca (Moher et al. 2019), gubitak vremena kako bi se članak povukao (Chambers 2019), nepovjerenje u nauku (Habibzadeh i Simundic 2017). Ipak, za one koji su stekli dovoljno iskustva, situacija se razlikuje. Jedni su iznervirani, drugi više ne reaguju. Osobno, osjetio sam moralnu dužnost da sistematično pročitam te pozive između redova i pronađem trendove i elemente koji su u tim člancima, prije svega da upozorim druge istraživače na opasnost koja se krije iza takvih poziva (Petrişor 2016, 2017, 2018).

Cilj ove studije je da donese više dokaza da grabežljivi izdavači imaju sjedište u zemljama koje ne poštuju ustaljene istraživačke standarde Zapada i nemaju naučne temelje, ne pridržavaju se istraživanja pa čak ni opće etike i nemaju nikakve granice u ostvarivanju svog cilja zarade obmanjujući svoje potencijalne žrtve, kako to i naslov članka sugeriše.

\section{Podaci i metode}

Nekoliko studija se bavilo pitanjima engleskog jezika u vezi sa grabežljivim časopisima. Soler i Cooper (2019) vjeruju da je opetovano odbijanje radi nivoa poznavanja engleskog jezika, koje izdavači često koriste kao 'blaži' razlog da odbiju članke koji vjerovatno neće dobiti dovoljno navoda umjesto 'oštrijeg' nedostatka dubine istraživanja (Petrişor 2020), favoriziralo grabežljive časopise koji se ne ustručavaju prihvatiti bilo kakvu prijavu, bez obzira na nivo jezika, samo ako autori plate naknadu. Za neizvorne govornike engleskog jezika, strah od odbijanja radi nivoa poznavanja jezika je opravdan (Kurt 2018). Ovo bi moglo biti ključno u zemljama u kojima, kako navodi Ebadi i Zamani (2018), iako engleski nije službeni jezik, kriteriji za promicanje i finansiranje zahtijevaju od autora da objavljuju članke na engleskom jeziku. U tom okruženju, Petrişor (2017) pokazuje da grabežljivi pozivi dolaze od ljudi s vrlo uobičajenim engleskim imenima, na 
people with very common English names, as indicated by the sender's name included in the e-mail address, in order to hide the real location of the senders. Other studies point out to the poor English as a common characteristic of these calls (Truth 2012; Bohannon 2013; Crawford 2014; Petrişor 2016); moreover, it encourages the non-native English speakers to submit their work (Petrişor 2016), especially in organizational contexts that do not ban publishing in predatory journals (Shaghaei et al. 2018).

A complex study by Markowitz et al. (2020) was based on an automated language analysis technique from the social sciences and the analysis of meta-linguistic properties of the websites of predatory journals. The main findings consisted of detecting more discrepancy terms and positive emotions, but fewer function words, including articles and prepositions, quantifiers, and causal terms, patterns consistent with those from the deception literature, and more third-party email addresses, claims of false impact factors, fake fast peer review, and mimicked academic expertise.

On a different note, Bell (2017) sees the predatory publishers as a parody or (poor) mimicry of the legitimate ones; the elements used for justifying it deal, among others, with the language quality.

The phrasing of calls and website text may be an indication of the fact that these journals are based in the global South, including India, China and various parts of Africa (Mills and Inouye 2020). However, this is hard to ascertain, because the location is often disclosed (Petrişor 2016; Kurt 2018), or the publishers provide a fake location, and the location claimed by the call differs from the one of the server sending it (Petrişor 2018).

The examination of the above studies suggests that the empirical analysis of calls and websites is the only way to flag potentially predatory calls. The method used in this study was collect different calls, and organize them as "thematic samples"; the text analysis is used to pinpoint the strange, and often hidden, details supporting the study hypothesis. While this method has been used in other studies (Petrișor 2016, 2017, 2018), this article is rather different due to a special focus on the English language, which has been also investigated by other studies; the purpose is to look at the most extravagant way of phrasing the call and pleading for the submissions to their journal or conference. Although these 'outliers' are not representative for absolutely all calls, some of the distinctive features presented at their peak can be identified, to some extent, in all predatory calls.

The samples are organized starting from a recent predatory call for papers, with references to similar illustrations and a discussion of the implications što ukazuje ime pošiljatelja uključeno u adresu epošte, kako bi se sakrila stvarna lokacija pošiljatelja. Druge studije pokazuju da je uobičajena karakteristika ovih poziva loš engleski jezik (Truth 2012; Bohannon 2013; Crawford 2014; Petrişor 2016); štaviše, ohrabruju neizvorne govornike engleskog jezika da dostave svoj rad (Petrişor 2016), pogotovu u organizacijskom kontekstu koji ne zabranjuje objavljivanje u grabežljivim časopisima (Shaghaei et al. 2018).

Kompleksna studija Markowitz et al. (2020) bazirana je na automatiziranoj tehnici analize jezika društvenih nauka i analizi metalingvističkih svojstava web stranica grabežljivih časopisa. Glavni nalazi se sastoje od uočavanja više neskladnih pojmova i pozitivnih emocija, a manje funkcionalnih riječi, uključujući članove, prijedloge, znakove i uzročne pojmove, obrazaca u skladu s onima iz literature o obmanjivanju te adresa e-pošte trećih strana, tvrdnji o lažnim faktorima utjecaja, lažnoj brzoj recenziji i oponašanja akademske stručnosti.

S druge strane, Bell (2017) vidi grabežljive izdavače kao parodiju ili (loše) oponašanje legitimnih; elementi koji se koriste za njegovo opravdanje odnose se, među ostalim, na kvalitetu jezika.

Izražavanje u pozivima i tekstovima na web stranici može biti pokazatelj činjenice da časopisi imaju sjedište na globalnom jugu, uključujući Indiju, Kinu i razne dijelove Afrike (Mills i Inouye 2020). Međutim, to je teško utvrditi jer mjesto često nije prikazano (Petrişor 2016; Kurt 2018), ili izdavači daju lažnu lokaciju, a lokacija na koju se poziva poziv razlikuje se od lokacije servera koji je šalje (Petrişor 2018).

Ispitivanje gore navedenih studija sugeriše da je empirijska analiza poziva i web stranica jedini način za označavanje potencijalno grabežljivih poziva. Metoda korištena u ovom istraživanju bila je prikupljanje različitih poziva i njihovo organiziranje u "tematske uzorke"; analiza teksta koristi se za određivanje čudnih, a često i skrivenih detalja koji podupiru hipotezu studije. Iako se ova metoda koristila u drugim studijama (Petrişor 2016, 2017, 2018), ovaj je članak dosta drugačiji zbog posebnog fokusa na engleski jezik, što su također istraživale druge studije; svrha je proučiti najekstravagantniji način formulisanja poziva i molbi za prijave radova za njihov časopis ili za konferenciju. Iako ove 'vrijednosti' nisu primjenjive na apsolutno sve pozive, neka od karakterističnih obilježja koja su najizraženije predstavljena, mogu se u određenoj mjeri identificirati u svim grabežljivim pozivima.

Primjeri su organizirani počevši od novijeg grabežljivog poziva za radove, s referencama na slične illustracije i raspravom o implikacijama i, gdje god je to moguće, o dinamici. Sveukupno, prezentacija je koncipirana na temelju strukture poziva, od 
and, wherever available, dynamics. Overall, the presentation is conceived based on the structure of the call, from the name of sender to the subject and body of the call, with a deeper examination of the later. Since the article focuses on language issues, the mistakes present in the calls were not corrected, but underlined using a bold font.

\section{Thematic samples}

\subsection{Endless resources in inventing the names}

There are some studies that have dealt with the (pretended) name of the sender. Petrişor (2016) notices that most often the names are common and the address seems to match the sender's name, but cites some instances when the name of the sender and the one of the person actually signing the call for papers differed, although both seem to be personal names. Other categories include a generic name, such as "Editor", "Editorial Office", or "Editorial Assistant". In a later study (Petrişor 2017), strange names, like "Stallone Sylvester" and "Elvis", are mentioned. The strange names are also mentioned by Bell (2017), who discusses the cartoon-like appearance of "Grace Groovy", signing a message from a predatory journal. Petrişor (2018) mentions, as spamming strategies also used by the predatory journals, the use of "common or attractive names" and indication of the doctoral degree, meant to "make the message more trustworthy".

An analysis of the recent calls reveals several categories. Some journals do no longer disclose their origin, and messages are signed by Sandeep Sharma <info@zedudaba.online>, Prof. Shamim Ahmad, or an official address of the journal: netjourn.mri@ netmails.ga. Others continue to use common names and addresses, such as Jones Paul < pjones420@ yahoo.com>, Jennifer Collymore <jennifer.collymore03@yahoo.com>. A new category uses even the name and address for boosting their importance: rank<rank41editor@rediffmail.com>, best < best65office@rediffmail.com>, or journal chief11401 $<$ journal_chief52149@excite.com>. The most interesting category is made up of the really strange names. The hijacked copy of Wulfenia, claimed to be also based in Vienna, Austria is signed by "Professor Vienna S. Franz", which is in line with Bell's (2017) idea of the predatory journals being a parody.

It is also important to note that the presence of English names among those who send out the call or endorse it by apparently forwarding it highly contrasts with the poor English language of the call, a clear indication of the true geographic location of the predatory journals (Mills and Inouye 2020). imena pošiljatelja do predmeta i i samog sadržaja poziva, s dubljim ispitivanjem kasnijeg. Budući da se članak fokusira na jezička pitanja, pogreške prisutne u pozivima nisu ispravljene, već su podcrtane podebljanim fontom.

\section{Tematski uzorci}

\subsection{Beskonačni izvori u izmišljanju imena}

Postoje neke studije koje su se bavile (lažnim) imenom pošiljatelja. Petrişor (2016) primjećuje da su najčešće uobičajena imena te se čini da adresa odgovara imenu pošiljatelja, ali navodi neke slučajeve kada su se ime pošiljatelja i ime osobe koja je zapravo potpisala poziv za podnošenje ponuda razlikovala, iako se čini da su oba imena lična. Ostale kategorije uključuju opće nazive, poput "Urednik", "Uredništvo" ili "Pomoćnik urednika". U kasnijim studijama (Petrişor 2017) spominju se neobična imena, poput "Stallone Sylvester" i "Elvis". Neobična imena također spominje Bell (2017), koji raspravlja o "Grace Groovy" kao pojavi iz crtića, u potpisu poruke grabežljivog časopisa. Petrişor (2018) kao strategiju neželjene pošte koju također koriste grabežljivi časopisi spominje upotrebu "uobičajenih ili atraktivnih imena", kao i naznaka doktorske titule, s namjerom da "poruku učini pouzdanijom".

Analiza nedavnih poziva otkriva nekoliko kategorija. Neki časopisi više ne otkrivaju svoje porijeklo, a poruke potpisuje Sandeep Sharma <info@ zedudaba.online>, prof. Shamim Ahmad, ili službena adresa časopisa: netjourn.mri@netmails.ga. Drugi nastavljaju s korištenjem uobičajenih imena i adresa kao što su Jones Paul < pjones420@yahoo. com>, Jennifer Collymore $<$ jennifer.collymore03@ yahoo.com>. Nova kategorija koristi čak imena i adrese koje uveličavaju njihovu važnost: rank $<$ rank41editor@rediffmail.com>, best < best65office@ rediffmail.com>, ili journal chief11401<journal chief52149@excite.com>. Najinteresantnija kategorija je izmišljena od veoma čudnih imena. Ukradenu kopiju Wulfenije, za koju se tvrdi da je također sa sjedištem u Beču u Austriji, potpisuje "Professor Vienna S. Franz", što je u skladu s Bellovom (2017) idejom da su grabežljivi časopisi parodija.

Također je važno napomenuti da je prisutnost engleskih imena među onima koji šalju poziv ili ga očito podržavaju prosljeđujući ga, koja je u izrazitoj suprotnosti s lošim engleskim jezikom poziva, jasan pokazatelj stvarne geografske lokacije grabežljivih časopisa (Mills i Inouye 2020).

\subsection{Hvaljenje nepoznatog autora}

(1) "Datum: Pon, 28 dec 2020 07:26:21 +0000

Predmet: AW: Doctor: Acknowledgement: Toxicology

Poslao: "Advanced Journal of Toxicology: Current Rese- 


\subsection{Praising an unknown author}

(1) "Date: Mon, 28 Dec 2020 07:26:21 +0000

Subject: AW: Doctor: Acknowledgement: Toxicology

From: "Advanced Journal of Toxicology: Current Research"<review@sendpaper.info>

Dear Doctor,

Can we have your article for successful release of an upcoming issue towards our Advanced Journal of Toxicology: Current Research https://onlinemypaper.com/index. php/campaigns/wj8887bk6t259/track-url/vg861 evcwb734/2ae31aea693ac5d43238d94a8bc64de468c6538e?

In fact, we need one article to accomplish the Issue prior January 10, 2020; for our journal which possesses PubMed indexed articles followed by indexing in reputed online repositories.

If this is a short notice please do send 2-page opinion article, short Communication, Mini Review, Case Reports..., as we hope 2-page article isn't time taking for an eminent author like you.

I believe in you that your eminent manuscript brings out the best citation to our journal.

We hope that you will be able to respond positively to this invitation, and we look forward to hear from you shortly. Anticipate your promising response.

Regards,

Kevin Parker

Editorial Assistant

SciRes Literature LLC

Middletown

DE 19709

United States"

The call is sent to an anonymous "Doctor" (note the impersonal addressing style), yet the recipient doctor is eminent and able to produce shortly a twopage eminent document (its content or type does not matter for the journal), which "brings out the best citation to our journal". Please note the overuse of "eminent", which, according to the contemporary English dictionary, means "famous, respected, or important", and is an attribute of a person, not of an object (document). Also, what is the best citation? It is hard to answer, given the extremely poor English, strongly contrasting with a "Kevin Parker" based in Middletown, DE, United States, signing the call. It could mean that the article brings many citations, but also that it is cited by the top journals; in any case, this can be hardly expected from an anonymous "Doctor". Last but not least, please note the contrast between this fake respect showed to the recipient, and the idea of soliciting a short manuscript, "whatever", just to close up the upcoming issue.

(2) "Eminent Support

Date: Jan 7 at 11:06 AM

From: environmentalcorpuspublishers@gmail.com <en- arch"<review@sendpaper.info>

Poštovani doktore,

Možemo li dobiti vaš članak za naš časopis Advanced Journal of Toxicology: Current Research i uspješno objavljivanje nadolazećeg broja https://onlinemypaper. com/index.php/campaigns/wj8887bk6t259/track-url/vg8 61 evcwb734/2ae31aea693ac5d43238d94a8bc64de468c $6538 \mathrm{e}$ ?

Zapravo, potreban nam je jedan članak kako bismo završili broj prije 10. januara 2020; za naš časopis koji ima PubMed indeksirane članke, nakon čega slijedi indeksiranje u poznatim online repozitorijima.

Ako je ovo kratka obavijest, molim Vas pošaljite članak od 2 stranice, mišljenje, kratki izvještaj originalnog rada, mini prikaz, izvještaj o slučajevima... jer se nadamo da članak od 2 stranice ne oduzima vrijeme uglednog autora poput Vas. Vjerujem u Vas da Vaš ugledni rukopis donosi najbolju citiranost našem časopisu.

Nadamo se da ćete moći pozitivno odgovoriti na ovaj poziv i radujemo se što ćete se uskoro javiti. Očekujući Vaš obećavajući odgovor.

Pozdravi,

Kevin Parker

Pomoćnik uredništva

SciRes Literature LLC

Middletown

DE 19709

United States"

Iako je poziv poslat anonimnom "doktoru" (obratite pažnju na neosobni stil obraćanja), ipak je primalac doktor "eminentan" i može brzo napisati značajan dokument od dvije stranice (njegov sadržaj ili vrsta nisu važni za časopis), koji "donosi najbolju citiranost našem časopisu". Primijetite prekomjernu upotrebu riječi "eminentan", što prema savremenom engleskom rječniku znači "poznat, poštovan ili važan" te je osobina osobe, a ne predmeta (dokumenta). Također, koja je najbolja citiranost? Teško je odgovoriti, s obzirom na izrazito loš engleski, koji je u jakoj suprotnosti s "Kevinom Parkerom" sa sjedištem u Middletownu, DE, Sjedinjene Države, koji potpisuje poziv. To bi moglo značiti da članak donosi mnogo citata, ali i da ga citiraju vodeći časopisi; u svakom slučaju, to se teško može očekivati od anonimnog "doktora". I na kraju, ali ne i najmanje važno, primijetite kontrast između ovog lažnog poštovanja koje je iskazano primatelju i ideje da se traži kratak rukopis, "svejedno", samo kako bi se završio nadolazeći broj.

(2) "Eminentna podrška

Datum: Jan 7 at 11:06 AM

Od: environmentalcorpuspublishers@gmail.com <envi- 
vironmentalcorpuspublishers@gmail.com>

Dear Dr. Alexandru Ionuţ PETRIŞOR,

Hope you are doing well.

Well, we would like to publish your article in the "January Edition". To initiate this edition, we need your article, so can I have your support?

In fact, your trust in my efforts is the highest form of our motivation, I believe in you that you are eminent manuscript brings out the best citation to our Journal.

Acknowledge this email within $24 \mathrm{hrs}$.

Regards,

Jennifer Davila

Environmental Sciences and Ecology: Current Research (ESECR)"

Although very similar to the previous one, this message shocks through the overuse of the word "eminent". The support is eminent, the manuscript is eminent... everything seems to be eminent apart from any person. According to the current English use, the word "eminent" is an attribute of a person or organization, not of abstract concepts (support) or unanimated objects (articles). The strategy of overusing the boosting language to praise the authors is common to the predatory journals. The peak is cited by Petrişor (2016): Dear Dr... Greetings. First of all, our Organization wants to honor you for your achievement and Awards. Your path and experience may guide many young researchers to be a successful scientist in the world. With your majestic presence which will take the conference to a supreme level and also will support to harness the current and future research in Cell Science \& Stem Cell Research.

\subsection{Subjects and content beyond the regular ones}

Probably on the lowest level of personalizing the call to increase its credibility (Petrişor 2016), a call would use "Call for papers" (with the often mistaken version "Call for paper"), and start abruptly presenting the journal. The question is: what is the upper limit? Three examples are presented below.

(1) Subject: IOSR JOURNALS :: What should be the quality of Good Journals?

From: Sandeep Sharma <info@zedudaba.online>

Date: 19-Nov-20, 13:51

What should be the quality of Good Journals?

1. Journal should be atleast 10 year old. So that community should be well known to journals.

2. Published articles should be cited more than 15 for each article on average. If it is performed for other published articles, it will perform for your article also.

3. All articles should be searchable on google.

4. Journal should publish regularly. There should be no regularity in issues.

5. At least $50 \%$ of published articles should relate to ronmentalcorpuspublishers@gmail.com>

DragiDr. Alexandru Ionuţ PETRIŞOR,

Nadam se da ste dobro.

Pa, htjeli bismo Vaš članak objaviti u "januarskom izdanju". Za pokretanje ovog izdanja potreban nam je Vaš članak pa možemo li dobiti Vašu podršku?

Zapravo, Vaše povjerenje u moje napore najviši je oblik naše motivacije, vjerujem u Vas da će ugledni rukopis donijeti najbolju citatnost našem časopisu.

Potvrdite ovu e-poruku u roku od 24 sata.

Pozdrav,

Jennifer Davila

Environmental Sciences and Ecology: Current Research (ESECR)"

Iako vrlo slična prethodnoj, ova poruka šokira zbog prekomjerne upotrebe riječi “eminentni”. Podrška je eminentna, rukopis je eminentan... čini se da je sve eminentno osim osoba. Prema trenutnoj upotrebi u engleskom, pridjev "eminentni” koristi se uz osobu ili organizaciju, a ne apstraktni pojam (podrška) ili neživi objekt (članak). Strategija prekomjernog korištenja hvalisavog jezika kako bi se pohvalili autori zajednička je grabežljivim časopisima. Vrhunac je naveo Petrişor (2016): Dragi dr... Pozdrav. Prije svega, naša organizacija želi Vam odati počast zbog Vašeg postignuća i nagrada. Vaš put i iskustvo mogli bi voditi mnoge mlade istraživače do uspjeha u svijetu. Uz vašu veličanstvenu prisutnost koja će konferenciju podići na najvišu razinu, a također će podržati korištenje trenutnih i budućih istraživanja $u$ Cell Science \& Stem Cell Research.

\subsection{Predmeti i sadržaji izvan uobičajenih}

Vjerojatno na najnižoj razini personalizacije poziva kako bi se povećala njegova vjerodostojnost (Petrişor 2016), poziv bi koristio "Poziv za radove" (s često pogrešnom verzijom "Poziv za rad"), i počeo naglo predstavljati časopis. Pitanje je: koja je gornja granica? Tri primjera predstavljena su u nastavku.

(1) Predmet: IOSR JOURNALS :: Kakva bi trebala biti kvaliteta dobrih časopisa?

Od: Sandeep Sharma <info@zedudaba.online>

Datum: 19-Nov-20, 13:51

Kakva bi trebala biti kvaliteta dobrih časopisa?

1. Časopis bi trebao biti star najmanje 10 godina. Kako bi zajednica trebala biti dobro poznata časopisima.

2. Objavljeni članci bi trebali biti citirani više od 15 za svaki članak u prosjeku. Ako se izvodi za druge objavljene članke, on će se izvesti i za vaš članak.

3. Svi članci bi trebali biti pretraživi na googleu.

4. Časopis bi trebao redovno izlaziti. Ne bi trebalo biti pravilnosti u izdanjima.

5. Najmanje $50 \%$ objavljenih članaka trebalo bi se odnositi na nešto drugo osim na vašu zemlju. Kako bi se vaš 
something other than your country. So that your article can be popularised in the worldwide community.

ALL OF ABOVE QUALITY, you can get in IOSR Journals

[message continues]"

Obviously, living aside the misspellings, strange capitalization and elementary grammar mistakes, the message is hilarious by the fact that the English level is so poor, that the message is a counter-advertisement. Line 1 says that within 10 years the journal would get to know the (probably research) community, when actually the interest is to make the journal known to it. The funnies is line 4, with two messages contradicting each other, the first one saying that the journal should be published on a regular basis, and the second, exactly the opposite. In addition to the poor phrasing, the message shows that the authors are completely outside of understanding how science works. For example, line 2 suggests that the citations are a result of the quality of the journal, and not of the submissions. Line 3 suggests that authors document their work using Google (not even Google Scholar!) instead of accessing special full text databases, or directly the journal websites. Line 5 makes a strange connection between the geographical area covered by an article and the journal circulation, inferring that an article covering topics related to a region will be made known abroad because the other articles from the journal cover different regions. Even the idea of "geographical coverage" ties to the poor research depth expected by the journal, meaning that they are likely to feature local case studies instead of studies showing sufficient research depth to be understood by a broader audience.

It has to be stressed out that the creativity of this very insistent spammer, IOSR Journals, does not stop here; 4 messages were received 1 January 2021 only to one address, with the subjects: "quality of Good Journal :: Happy new year 2021", received 00:09:53 +0000 from IOSR Journal<info@amzun.online> (please note the odd subject, combining the older one with the greetings); "IOSR JOURNALS Cheers to health, happiness, and prosperity in 2021", received 10:03:47 +0000 from IOSR JOURNALS <info@xumd.online> (due to the poor English, the subject looks like the title of the song, instead of a greeting); "IOSR JOURNALS May your New Year bring you reasons to smile!", received 17:40:43 +0000 from IOSR JOURNAL <info@zedudaba.online>; and "I wish you many blessings !", received 18:49:11 +0000 from IOSR Journal<info@toughnut. info> (please note the unusual use of the singular "I" in a message coming from a journal; also, the "many blessings" resembling the Nigerian scam: "Dear God's elect, I believe you will do better than I think [...] when my late husband was alive he deposited the sum of \$12.2 USD Million (Twelve million two hundred thousand dollars) with a bank in Ouagadougou Burkina Faso [...] Remain blessed. Yours Sister Mrs Kadi karim”). In addition to članak mogao popularizirati u svjetskoj zajednici.

SVU NAVEDENU KVALITETU možete dobiti u IOSR časopisima

[poruka se nastavlja]"

Očito, ako se zanemare pravopisne pogreške, čudna velika slova i elementarne gramatičke greške, poruka je urnebesna zbog činjenice da je engleski toliko slab da je poruka kontrareklama. Redak 1 kaže da bi časopis u roku od 10 godina upoznao (vjerovatno istraživačku) zajednicu, a zapravo im je interes da časopis bude poznat. Najzabavniji je redak 4, s dvije proturječne poruke, jer prva kaže da bi časopis trebao redovno izlaziti, a druga upravo suprotno. Osim loših rečenica, poruka pokazuje da autori apsolutno ne razumiju kako nauka funkcioniše. Na primjer, redak 2 sugeriše da je citatnost rezultat kvaliteta časopisa, a ne podnesaka. Redak 3 sugeriše da autori dokumentiraju svoj rad pomoću Googlea (čak ni pomoću Google Znalca!) umjesto pristupa posebnim bazama podataka sa cjelovitim tekstovima ili izravno web stranicama časopisa. Redak 5 na čudan način povezuje geografsko područje koje pokriva članak i distribuciju časopisa, zaključujući da će članak koji pokriva teme vezane za regiju biti poznat u inostranstvu jer ostali članci iz časopisa pokrivaju različite regije. Čak i ideja o "geografskoj pokrivenosti" povezana je s lošom razinom istraživanja koju očekuje časopis, što znači da će vjerovatno sadržavati lokalne studije slučaja umjesto studija koje pokazuju dovoljnu dubinu istraživanja kako bi ih mogla razumjeti šira publika.

Mora se naglasiti da se kreativnost ovog vrlo upornog pošiljaoca neželjene pošte, IOSR časopisa, ne iscrpljuje na ovom; četiri poruke poslate su 1. januara 2021. na jednu te istu adresu, s temama: "Kvaliteta dobrog časopisa :: Sretna nova 2021.", primljena 00:09:53+0000 od IOSR Journal <info@ amzun.online > (primijetite čudan predmet poruke koji kombinira starije poruke i pozdrave); "IOSR ČASOPISI nazdravljaju za zdravlje, sreću i napredak u 2021.", primljena 10:03:47 +0000 od IOSR JOURNALS <info@xumd.online> (zbog lošeg engleskog, predmet izgleda kao naslov pjesme, umjesto pozdrava); "IOSR JOURNALS Neka vam Nova godina donese razloge za osmijeh!", primljena 17:40:43+0000 od IOSR JOURNAL <info@zedudaba.online>; i “"̌elim vam mnogo blagoslova!", primljena 18:49:11+0000 od IOSR Journal <info@ toughnut.info $>$ (imajte na umu neobičnu upotrebu jednine "Ja" u poruci koja dolazi od časopisa; također, "mnogo blagoslova" liči na Nigerijsku prevaru: "Dragi Božji izabraniče, vjerujem da će Vam biti bolje nego što mislim [...] kad je moj pokojni muž bio živ, položio je svotu od 12,2 miliona američkih dolara (Dvanaest miliona i dvjesto hiljada dolara) u banku Ouagadougou Burkina Faso [...] Ostanite blagoslovljeni. Tvoja Sestra Gđa Kadi karim"). 
the elements pointed out, it is interesting to see that each invitation appears to come from a different address, although the "Reply-To" address is IOSR Journal <support@iosrmail.org > in all cases.

(2) "Subject: UGC Approved Journal Score Your Rank by Publishing Research Paper with International High Impact Factor Journal

From: "Editor - IERJ"<info@thewriterspublication. co.in>

Date: Sat, June 10, 2017 12:22”

"From: IOSR JOURNALS <info@zedudaba.online>

Subject: IOSR Articles Journal

Date: Date: Fri, 25 Dec 2020 10:26:50 +0000

[...]

(we have indexed all 2019 and 2020 articles in Indian Citation Index. [...] It is one of the top approved and authorized Indexing of Asia. [...]"

"From: IOSR JOURNALS <info@toughnut.info>

Subject: IOSR Journals got 9 Ranking by AQCJ

Date: Date: Mon, 28 Dec 2020 09:43:56 +0200 (EET)

$[\ldots]$

We are happy to announce to you that the International Organization of Scientific Research Journals have come under AQCJ - 2020 Top 10 Journals Ranking.

IOSR Journals got 9 Ranking by AQCJ (African Quality Center for Journals) - Top 10 Journals Ranking. [...]"

"Date: Thu, 31 Dec 2020 00:39:59+0000

From: Quest Journal<info@xumd.online>

Subject: Quest International Journal

[...]

QUEST Journals got 9th Ranking by AQCJ (African Quality Center for Journals) - Top 10 Journals Ranking. $[\ldots]^{\prime \prime}$

UGC is the University Grants Commission of India, a body funding Indian education based on the scientific output of the universities. In their turn, universities set further pressure on the professors to publish. In 2017, the UGC started to create white lists of journals that have acceptable standards; only publications in these journals are accepted for a grant proposal to be funded. These references to Indian or African organizations and indexing services are attempting to provide additional legitimacy for the journal. However, since the call is not targeted (e.g., to the Indian or African universities, professional associations, etc.), but sent out randomly, such an argument, not appealing for any potential author from outside of India or Africa, is good only for providing additional evidence for the geographical location of predatory journals, in line with Mills and Inouye (2020).

Also, please note the examples of two different journals (in reality, the number is greater, only two were chosen for illustrating purposes) receiving the same African Quality Center for Journals (AQCJ) rank; this is a first sign able to raise suspicions. Most often, such endorsements have
Osim istaknutih elemenata, zanimljivo je da izgleda da svaki poziv dolazi s druge adrese, iako je adresa za odgovor u svim slučajevima IOSR Journal <support@iosrmail.org>.

(2) "Predmet: UGC odobrena ocjena časopisa Vaš rang objavom istraživačkim radom u časopisu Međunarodno visokog faktora uticaja

Od: "Editor - IERJ"<info@thewriterspublication.co.in> Datum: Subota, Juni 10, 2017 12:22”

“Od: IOSR JOURNALS <info@zedudaba.online>

Subject: IOSR Articles Journal

Date: Date: Petak, 25 dec 2020 10:26:50 +0000

[...]

(indeksirali smo sve članke za 2019. i 2020. u Indian Citation Indexu (Indijska citatna baza) [...] Jedan je od najboljih odobrenih i ovlaštenih Indeksa Azije [...]"

“Od: IOSR JOURNALS <info@toughnut.info>

Predmet: IOSR Journals got 9 Ranking by AQCJ

Datum: Pon, 28 dec 2020 09:43:56 +0200 (EET)

$[\ldots]$

Sretni smo što vas možemo obavijestiti da su Međunarodna organizacija naučnoistraživačkih časopisa dospjeli na ljestvicu 10 najboljih časopisa AQCJ - 2020.

IOSR časopisi su dobili 9. mjesto prema AQCJ (African Quality Center for Journals / Afrički centar za kvalitetu časopisa) - Top 10 časopisa. [...]"

"Datum: Četvrtak, 31 dec 2020 00:39:59 +0000

Od: Quest Journal<info@xumd.online>

Predmet: Quest International Journal

[...]

QUEST časopisi su dobili 9. mjesto prema AQCJ-u (African Quality Center for Journals / Afrički centar za kvalitetu časopisa) - Top 10 časopisa [...]”

UGC je Univerzitetska komisija za stipendije u Indiji, tijelo koje finansira indijsko obrazovanje na temelju naučnih rezultata univerziteta. S druge strane, univerziteti vrše daljnji pritisak na profesore da objavljuju radove. Godine 2017. UGC su počeli kreirati bijelu listu časopisa koji imaju prihvatljive standarde; samo se radovi u tim časopisima prihvataju za finansiranje prijedloga bespovratnih sredstava. Ove reference na indijske ili afričke organizacije i usluge indeksiranja pokušavaju obezbijediti dodatni legitimitet časopisu. Međutim, budući da poziv nije ciljan (npr., na indijske ili afričke univerzitete, strukovna udruženja itd.), nego je poslat nasumično, takav argument, koji nije privlačan za bilo kojeg potencijalnog autora izvan Indije ili Afrike, dobar je samo za pružanje dodatnih dokaza o geografskom položaju grabežljivih časopisa, u skladu s Millsom i Inouyeom (2020).

Također, obratite pažnju na primjere dva različita časopisa (u stvarnosti je broj veći, samo su dva izabrana radi ilustracije) sa dobijenim istim mjestom na rang-listi Afričkog centra za kvalitetu časopisa (AQCJ); ovo je prvi znak koji može izazvati sumnju. Najčešće su ta- 
a dubious quality. The AQCJ website is down, but it can be accessed through the Internet archive up to 23 June 2020 (https://web.archive.org/web/20200623200253/ http://www.aqcj.org/index.html); it offers very little information, the English level is poor, and an "Impact Factor" is advertised. The particular AQCJ Impact Factor is mentioned by Xia and Smith (2018) as an alternative "tailored to poor publishing practice, with many irreproducible measures", and by Dadkhah et al. (2017) on their "List of Misleading Metrics".

(3) "We sincerely request you to submit your Articles IJHSSE

From: Editor_IJHSSE <info@oajour.com>

Date: Jan 12 at 2:51 AM

[...] Given the advancement and novelty in your field, it is more imminent than ever before to get your research published. So, we kindly invite you with sincerity to contribute your unpublished manuscripts.

Looking forward to your favorable reply.

Yours sincerely,

Editorial Office"

Let us examine a little bit more the text. The subject emphasizes the sincerity idea. Why is it necessary? Judging by the strict sense of the phrase, the opposite of a sincere invitation is an insincere one. But what does it mean? Normally, it means that people are invited to submit, but actually the journal does not welcome their submissions. Obviously, this is not the intention of the text. The real sense is that predatory publishers are, by their nature, deceptive, and the overemphasized sincerity refers to the senders, trying to hide their real intention, and not to the call itself. In plain English, this is an additional proof that the predatory publishers are wolves in sheep clothes.

Although the three examples are the most relevant, the list does not stop here. A call for papers from the International Journal of Humanities and Social Science Invention, presented in the thematic sample no. 5, has the subject "Best Impact Factor Journal". This advertisement makes no sense, because the term "impact factor" is a trademark of Clarivate Analytics, and in the most recent rankings (Journal Citation Reports), the best impact factor, meaning the highest (note the poor English) belongs to the Cancer Journal for Clinicians (292.278 in 2019).

\subsection{Advertising for the unneeded gifts and justifying the quality in a strange way}

"Subject: Recommended by the Reviewers

From: best < best65office@rediffmail.com>

Date: Dec 17 at 8:01 AM

International Journal of Modern Engineering Research

ISSN: 2249-6645 kve preporuke sumnjive kvalitete. Web stranica AQCJ je nedostupna, ali joj se može pristupiti putem stranice Internet archive do 23. juna 2020. (https://web.archive. org/web/20200623200253/http://www.aqcj.org/index. html); nudi vrlo malo informacija, nivo engleskog je loš, a oglašava se i "Faktor uticaja". Posebni AQCJ faktor uticaja spominju Xia i Smith (2018) kao alternativu "prilagođenu lošoj izdavačkoj praksi, s mnogim neponovljivim mjerama", kao i Dadkhah et al. (2017) na njihovoj listi "List of Misleading Metrics" (Lista zavaravajućih pokazatelja).

(3) "Iskreno Vas molimo da prijavite svoje članke - IJHSSE

Od: Editor_IJHSSE <info@oajour.com>

Datum: Jan 12 u 2:51

[...] S obzirom na napredak i novitete u Vašem području, objaviti Vaše istraživanje sada je neizbježno. Stoga vas ljubazno i iskreno pozivamo da doprinesete svojim neobjavljenim rukopisima.

Radujemo se vašem pozitivnom odgovoru.

S poštovanjem,

Redakcija"

Pogledajmo još malo tekst. Naslov naglašava ideju iskrenosti. Zašto je to potrebno? Prema o osnovnom značenju te fraze, suprotnost iskrenom pozivu je neiskreni poziv. Ali što to znači? Obično to znači da su ljudi pozvani da ih pošalju radove, ali zapravo časopis ne pozdravlja njihove podneske. Očigledno, to nije namjera teksta. Pravi je smisao da su grabežljivi izdavači po svojoj prirodi prevaranti, a pretjerano naglašena iskrenost odnosi se na pošiljatelje, pokušavajući sakriti njihovu stvarnu namjeru, a ne na sam poziv. Na jednostavnom engleskom, ovo je dodatni dokaz da su grabežljivi izdavači vukovi u ovčijoj koži.

Iako su tri primjera najrelevantnija, popis ne staje ovdje. Poziv za radove iz časopisa International Journal of Humanities and Social Science Invention, predstavljen u tematskim uzorcima br. 5, ima naslov "Časopis sa najboljim faktorom uticaja". Ovaj oglas nema smisla, jer je termin "faktor utjecaja" zaštićena oznaka Clarivate Analyticsa, a na najnovijoj ljestvici rangiranja (Journal Citation Reports) najbolji faktor uticaja, tj. najviši (primijetite loš engleski), pripada časopisu Cancer Journal for Clinicians (292.278 u 2019).

\subsection{Oglašavanje nepotrebnih darova i opravdavanje kvalitete na čudan način}

"Predmet: Preporučuju recenzenti

Od: best < best65office@rediffmail.com>

Datum: Dec 17 u 8:01

International Journal of Modern Engineering Research

ISSN: 2249-6645

ISO 3297:2007 Certificirani međunarodni časopis 
An ISO 3297:2007 Certified International Journal

Features \& Benefits of IJMER Authors:

Number to every article.

IJMER provides individual "Hard copy of Certificate" to all Authors.

IJMER provides individual "Soft copy of Certificate" to all Authors.

[message continues]"

The above call lures the potential victims by providing two certificates, one electronic and the other mailed to the authors. But why would be an author interested in receiving a certificate attesting that the article was published, once the journal is online and everyone can see the article once it's published? Being familiar with the Algerian academic and research system, I know that the Algerian universities require such proofs for everything, from attending a conference to publishing an article. Such proofs are required for doctoral students to be allowed to defend their theses, or for academic promotion. The explanations are beyond the focus of this study. It can be easily assumed that the practice exists, certainly not in the Western world. Therefore, the advertisement suggests a clear target of the journal.

The advertisement of complying with an ISO standard is equally awkward. It can only be suspected that this may be an attempt to lure potential victims misleadingly taking ISO for ISI, the former (and initial) name of Clarivate Analytics (Institute for Scientific Information); apart for it, the ISO 3297:2007 (also mentioned in an e-mail received from: rank<rank41editor@rediffmail.com> November 20, 2020 at 6:53 AM), is just an indication of the fact that... the journal has an ISSN, a minimal requirement for a serial publication to exist. Petrişor (2016) mentions the reference in another predatory call of the ISO 9001:2008 standard, indicating the existence of a quality management system that can be used for internal application by organizations. None of these standards are likely to have any relationship with the quality of the journal, which is assessed in different ways.

The offer of a number for each article is meaningless. If the number would be the DOI unique identifier, this could be an advantage for the easy retrieval of the article, but simply assigning a number, since the article already has unique identifiers (e.g., the title) makes no sense.

Finally, the subject of the call is "Recommended by the Reviewers". This is as dubious as all other arguments used in the call. Reviewers can recommend the publication of a submission in a journal, with major, minor, or no changes. The only relationship between the quality of the journal and its reviewers could exist if the journal has a Board of Reviewers with prominent names; their presence is an implicit
Značajke i prednosti IJMER-ovih autora:

Broj svakom članku.

IJMER pruža individualnu "Štampanu kopiju certifikata" svim autorima.

IJMER pruža individualnu "Elektronsku kopiju certifikata" svim autorima.

[poruka se nastavlja]"

Gornji poziv mami potencijalne žrtve davanjem dva certifikata, jednog elektronskog, a drugog poslatog autorima poštom. No, zašto bi autor bio zainteresiran za dobivanje certifikata koji potvrđuje da je članak objavljen, nakon što časopis bude postavljen na mrežu i svi mogu vidjeti članak nakon objavljivanja? Poznajući alžirski akademski i istraživački sistem, znam da alžirski univerziteti zahtijevaju takve dokaze za sve, od sudjelovanja na konferenciji do objavljivanja članka. Takvi dokazi potrebni su kako bi doktoranti mogli odbraniti svoje teze, ili za akademsko napredovanje. Objašnjenja su izvan fokusa ove studije. Lako se može pretpostaviti da praksa postoji, ali zasigurno ne u zapadnom svijetu. Stoga oglas sugeriše jasnu metu časopisa.

Oglašavanje o usklađenosti s ISO standardom jednako je čudno. Može se samo sumnjati da je ovo možda pokušaj da se potencijalne žrtve namame pogrešno navodeći ISO za ISI, bivše (i prvobitno) ime Clarivate Analyticsa (Institute for Scientific Information); osim toga, ISO 3297:2007 (također spomenut u e-mail dobijenom od: rank $<$ rank41editor@rediffmail.com> November 20, 2020 at 6:53 AM), samo je pokazatelj činjenice da časopis ima ISSN, minimalni uslov za postojanje serijske publikacije. Petrişor (2016) spominje u drugom grabežljivom pozivu referencu ISO 9001:2008 standarda, što ukazuje na postojanje sistema upravljanja kvalitetom koji se može koristiti za interne primjene $u$ organizacijama. Vjerojatno nijedan od ovih standarda nema nikakve veze $\mathrm{s}$ kvalitetom časopisa, koja se ocjenjuje na različite načine.

Ponuda broja za svaki članak je besmislena. Ako bi broj bio jedinstveni identifikator DOI-a, to bi moglo biti prednost za lako pristupanje članku, ali jednostavno dodjeljivanje broja, budući da članak već ima jedinstvene identifikatore (npr. naslov), nema smisla.

Konačno, predmet poziva je "Preporučili recenzenti". To je sumnjivo kao i svi drugi argumenti koji se koriste u pozivu. Recenzenti mogu preporučiti objavljivanje rada u časopisu, s većim, manjim ili bez ikakvih promjena. Jedini odnos između kvalitete časopisa i njegovih recenzenata mogao bi postojati ako časopis ima Odbor recenzenata s istaknutim imenima; njihova je prisutnost implicitna potvrda kvalitete časopisa. To nije slučaj, jer web stranica časopisa (sada ugašena, ali dostupna putem stranice Internet archive: https://web.archive.org/ 
endorsement of the journal quality. This is not the case, as the journal website (dead now, but available through the Internet archive: https:/web.archive.org/web/20200819112939/http://www.ijmer. com/) does not display any list of the people who reviewed for the journal.

\subsection{No quality control}

"Subject: Invitation to Review: MRI-2020-016

From: netjourn.mri@netmails.ga <netjourn.mri@netmails.ga $>$

Date: Jun 10 at 6:28 PM

Dear Colleague,

We received a manuscript titled: Fishiness of piscine birds linked to absence of poisonous fungi but not pizza

I wish to find out if you can create time to review this manuscript and send it to us within ten days. Kindly send me an email to acknowledge the receipt of this mail.

Find the abstract below

\section{ABSTRACT}

What is a species? That is one of the main questions in evolutionary biology, ecology, and conservation biology. Another question is this one: Can the degree of fish-likeness in birds be linked to the absence of poisonous fungi? Sparked by recent major ornithological advances we set out to assess whether the reason that some birds are more morphologically similar to fish than others could be explained by the prevalence of fungi of mild to severe toxicity. Whereas birds of several taxonomic orders are partly or predominantly aquatic, few have adapted so strongly to an underwater lifestyle as penguins (Sphenisciformes). These both eat fish and look like fish (what's up with that?), and predominantly occur in the Antarctic region, where environmental conditions largely prohibit the growth of poisonous fungi. On the other hand, birds with traditionally bird-like morphology (e.g. Gallus gallus) as well as fish with fish-like morphology (e.g., Engraulis sp.) seem to mostly occur sympatrically with mushrooms on pizzas. We thus conclude that the absence of poisonous mushrooms has led to the pronounced fishiness of certain members of class Aves. Using a sophisticated statistical framework, we also uncover an unexpected interclass taxonomic relationship, and predict that the evolution of volant penguins as a result of climate change is mediated through shifted fungal distributions. Our study brings new and important perspectives to different fields, including climate change and invasion biology.

Keywords: Climate change, Convergent evolution, European Union, Mushrooms, Other stuff, R, Sphenisciformes, Taxonomic sensations.

Looking forward to your response and WE ALSO INVITE YOU TO SUBMIT YOUR MANUSCRIPT(S) FOR PUBLICATION.

Best regards,

Prof. Shamim Ahmad

Editor, Microbiology Research International

Net Journals." web/20200819112939/http://www.ijmer.com/) ne prikazuje listu osoba koje su recenzirale časopis.

\subsection{Nema kontrole kvalitete}

"Predmet: Poziv za recenziranje: MRI-2020-016

Od: netjourn.mri@netmails.ga <netjourn.mri@netmails. ga>

Datum: Juni 10 u 18:28

Dragi kolega,

Dobili smo rukopis pod naslovom: Fishiness of piscine birds linked to absence of poisonous fungi but not pizza / Ribolikost vodenih ptica povezana sa nedostatkom otrovnih gljivica, ali ne pizze

Želim znati možete li naći vremena za pregled ovog rukopisa i poslati nam ga u roku od deset dana. Ljubazno mi pošaljite e-mail da potvrdite primitak ove pošte.

Sažetak pronađite u nastavku

\section{SAŽETAK}

Šta je vrsta? To je jedno od glavnih pitanja u evolucijskoj biologiji, ekologiji i biologiji konzervacije. Drugo pitanje je ovo: Može li se stepen sličnosti s ribama kod ptica povezati s nedostatkom otrovnih gljivica? Potaknuti nedavnim velikim ornitološkim napretkom, odlučili smo procijeniti može li se razlog zašto su neke ptice morfološki sličnije ribama od drugih objasniti rasprostranjenošću gljiva blage do teške toksičnosti. Dok su ptice nekoliko taksonomskih redova djelomično ili pretežno vodene, rijetke su se tako snažno prilagodile podvodnom načinu života kao pingvini (Sphenisciformes). Obje jedu ribu i izgledaju poput ribe (kako to?), a pretežno se pojavljuju u antarktičkoj regiji, gdje okolišni uslovi uvelike zabranjuju rast otrovnih gljiva. Sa druge strane, ptice s tradicionalnom morfologijom ptica (npr. Gallus gallus), kao i ribe sa tradicionalnom morfologijom riba (npr. Engraulis sp.), čini se da se uglavnom simpatrično javljaju s gljivama na pizzama. Stoga zaključujemo da je odsutnost otrovnih gljiva dovela do izražene ribolikosti pojedinih pripadnika klase Aves (Ptica). Koristeći sofisticirani statistički okvir, otkrivamo i neočekivani međuklasni taksonomski odnos i predviđamo da je evolucija letećih pingvina rezultat klimatskih promjena posredovan kroz promijenjenu podjelu gljivica. Naša studija donosi nove i važne perspektive u različita područja, uključujući klimatske promjene i invazivnu biologiju.

Ključne riječi: klimatske promjene, konvergentna evolucija, Europska unija, gljivice, ostalo, R, Sphenisciformes, taksonomske senzacije

Radujemo se vašem odgovoru i POZIVAMO VAS DA POŠALJETE SVOJE RUKOPISE ZA OBJAVLJIVANJE.

Lijepi pozdrav,

Prof. Shamim Ahmad

Urednik, Microbiology Research International Net Journals."

Očigledno, svaki legitiman časopis primijetio bi da nešto "ne štima" sa ovim podneskom te ga odbacio. Činjenica da sam ga dobio kao potencijalni recenzent (i, prema Twitter objavi na: https://twitter.com/ 
Obviously, any legitimate journal would havenoticed the "fishiness" of this submission and desk-rejected it. The fact that I received it as a potential reviewer (and, according to the Twitter post at https://twitter. com/franzanth/status/1271532938740396033 others too) shows that the many sting experiments on the predatory journals had no effect. My personal guess is that the authors were having fun or planning a similar experiment with the ones presented in the following, but, although the call is over six months old, I have not seen the article published. If this is a sting experiment, then time is needed; Djuric (2015) published his sting experiment two years after it, and Bohannon (2013), some 10 months after the beginning of the experiment.

Two of the famous cases were already mentioned, but details are needed. Djuric (2015) submitted a bogus research article, citing Michael Jackson and the Serbian illustrated Mickey Mouse Magazine, to name only the few, to the Romania based Metalurgia International journal, which published it in exchange for a fee. It is worthy mentioning that the predatory status of Metalurgia International can be debated; despite its poor-quality control and money charges, the journal does not actively spam for papers, which is considered a defining feature of predatory publishers (Grudniewicz et al. 2019). The study of Bohannon (2013) is a typical sting experiment, where the author produced a bogus research article and submitted it to predatory and non-predatory journals (based on Beall's list), recording the outcome, and finding that most predatory publishers accepted it in exchange of a fee.

These experiments were not singular. Similar sting experiments were successfully made using a fake editor (Sorokowski et al. 2017). However, the really interesting stories are the individual one. A Star Trek fanatic, exasperated by the multiple predatory calls, wrote a bogus article relating a Star Trek episode describing the transformation of humans into amphibians at speeds exceeding the light one, signed by Star Trek fictional characters from the Starfleet Academy (including Admiral Janeway), and, after negotiating the fees, had it published for 50 US dollars (Paris et al. 2017). Equally exasperated by the multitude of calls, an author produced a document basically repeating the words "Get me off your $\mathrm{f}^{* * * i n g}$ mailing list" (as words and images), and sent it to one of the spamming predatory publishers (the International Journal of Advanced Computer Technology), who accepted it in exchange for a fee (Watson 2017).

Other "milder" examples include papers written using a program than builds up automatically articles that are correct from the grammar and spelling viewpoint, but make no scientific sense, like "Deconstructing Access Points" (by David Phillips and franzanth/status/1271532938740396033 i drugi također) pokazuje da mnogi eksperimenti da se razotkriju grabežljivi časopisi nisu imali učinka. Moje osobno nagađanje je da su se autori zabavljali ili planirali sličan eksperiment onom predstavljenom u nastavku rada, no, iako je poziv poslat prije više od šest mjeseci, nisam vidio da je članak objavljen. Ako je ovo eksperiment, potrebno je vrijeme; Djuric (2015) je objavio eksperiment nakon dvije godine, a Bohannon (2013), 10-ak mjeseci nakon početka eksperimenta.

Dva poznata slučaja već su spomenuta, ali potrebni su detalji. Djuric (2015) je poslao je lažni istraživački članak, citirajući Michaela Jacksona i srpski ilustrirani časopis Mickey Mouse, da navedemo samo neke, rumunskom časopisu Metalurgia International, koji ga je objavio uz novčanu naknadu. Vrijedi spomenuti da se o grabežljivom statusu časopisa Metalurgia International može raspravljati; uprkos lošoj kontroli kvalitete i zahtjevima za plaćanje, časopis ne šalje aktivno neželjenu poštu za radove, što se smatra ključnom značajkom grabežljivih izdavača (Grudniewicz et al. 2019). Studija Bohannona (2013) tipičan je eksperiment, u kojem je autor napravio lažni istraživački članak i poslao ga u grabežljive i negrabežljive časopise (na temelju Beallova popisa), bilježeći ishod i otkrivši da ga je većina grabežljivih izdavača prihvatila pod uslovom da se objavljivanje plati.

Ti eksperimenti nisu bili pojedinačni. Slični eksperimenti su uspješno napravljeni korištenjem lažnog urednika (Sorokowski et al. 2017). Međutim, veoma su zanimljive individualne priče. Fan Zvjezdanih staza, ogorčen višestrukim grabežljivim pozivima, napisao je lažni članak koji se odnosio na epizodu Zvjezdanih staza opisujući transformaciju ljudi u vodozemce brzinom većom od svjetlosti, koju su potpisali izmišljeni likovi iz Zvjezdanih staza s Akademije Zvjezdane flote (uključujući admiralku Janeway), i, nakon što je pregovarao o naknadama, objavio ga je za 50 američkih dolara (Paris et al. 2017). Jednako ogorčen mnoštvom poziva, autor je izradio dokument koji je u osnovi ponavljao riječi "Skini me s j....e mailing liste" (kao riječi i slike) i poslao ga jednom od grabežljivih izdavača s neželjenim porukama (International Journal of Advanced Computer Technology), koji ga je prihvatio pod uslovom da plati naknadu za objavljivanje (Watson 2017).

Drugi "blaži” primjeri uključuju radove napisane pomoću programa koji automatski stvaraju članke koji su ispravni s gramatičkog i pravopisnog stajališta, ali nemaju naučni smisao, poput "Dekonstrukcija pristupnih tačaka" (David Phillips i Andrew Kent), "Nezavisne, negativne, kanoničke Turingove strelice jednadžbi i problemi u primijenjenom formalnom PDE-u" (M. Rathke) ili članak Afrič- 
Andrew Kent), "Independent, Negative, Canonically Turing Arrows of Equations and Problems in Applied Formal PDE" (by M. Rathke), or the African Journal of Agricultural Research article "Mapping Indonesian paddy fields using multiple-temporal satellite imagery", by Nono Lee, Agnes Monica, and Inul Daratista. As nothing could flag the attention with respect to this article, it has to be said that it is a slightly modified copy of the Scholarly Journal of Agricultural Science article "Mapping Indonesian Rice Areas Using Multiple-Temporal Satellite Imagery", by Nono Lee and Pejabat Palsu. The two journals are both predatory, and the new author names belong to Indonesian pop stars.

The latest example shows that no attention is paid to the critical issue of plagiarism. Unfortunately, I can bring additional evidence for this. The article "Evolving strategies of the predatory journals" (Petrişor 2016) was plagiarized by the means of incorrect paraphrase. The author submitted it initially to the International Journal of Research in Education and Science; the Editor asked me to review it. I reported the plagiarism, and, ironically, the article dealing with predatory journals (with a message distorted occasionally by the poor English of the plagiarizer), ended by being published by a predatory journal, showing several "symptoms" described in the article (Hossain 2020).

\subsection{The graphic language}

An often-quoted Chinese proverb says that one image counts as much as 1,000 words. Figure 1 shows a call for papers from the International Journal of Humanities and Social Science Invention. The image is visually unpleasing, due to the extensive of violent colors, of too many font faces and sizes, apparently in a random way. This is a common feature of the predatory journals; Cukier et al. (2020) mention the 'look and feel' of unprofessionally designed websites of the predatory publishers.

\section{Discussions}

The findings of the study include, in a nutshell: (1) invented English names, meant to give the appearance that the calls come, as they claim, from the Western world, or that they are redirected (and implicitly endorsed) by Western scholars; (2) advertisements making no sense for the Western world, including meaningless certificates, claims of the recognition of the journal quality beyond the Western world; (3) lack of quality control, likely to indicate that a quality submission might share the same issue with pseudo-scientific articles; and (4) a poor graphic language, indicating the amateurish staff editing a predatory journal. All these confirm the hypothesis according to which predatory journal do kog časopisa za poljoprivredna istraživanja (African Journal of Agricultural Research) "Mapiranje indonezijskih neobrađenih polja pomoću viševremenskih satelitskih snimaka", Nono Leea, Agnes Monica i Inul Daratista. Budući da ništa ne može upozoriti na ovaj članak, valja reći da je to malo izmijenjena kopija članka časopisa Scholarly Journal of Agricultural Science "Mapiranje područja sa rižom u Indoneziji pomoću viševremenskih satelitskih snimaka" Nonoa Leeja i Pejabata Palsua. Oba časopisa su grabežljiva, a imena novih autora pripadaju indonezijskim pop-zvijezdama.

Najnoviji primjer pokazuje da se ne pridaje važnost kritičnom problemu plagijata. Nažalost, mogu donijeti dodatne dokaze za to. Članak "Razvojne strategije grabežljivih časopisa" (Petrişor 2016) plagiran je netačnom parafrazom. Autor ga je na početku poslao časopisu International Journal of Research in Education and Science (Međunarodni časopis za istraživanje u obrazovanju i nauci); urednik me je zamolio da ga pregledam. Izvijestio sam o plagijatu, a ironično je da je članak koji se bavio grabežljivim časopisima (s porukom koju je povremeno iskrivio loš engleski jezik plagijatora) završio objavljen u grabežljivom časopisu koji pokazuje nekoliko "simptoma" opisanih u članku (Hossain 2020).

\subsection{Grafički jezik}

Često citirana kineska poslovica kaže da jedna slika vrijedi hiljadu riječi. Slika 1 prikazuje poziv za radove iz časopisa International Journal of Humanities and Social Science Invention. Slika je vizuelno neugodna, zbog mnogo jakih boja, previše različitih izgleda i veličina slova, očito nasumičnih. Ovo je uobičajena odlika grabežljivih časopisa; Cukier et al. (2020) spominju 'izgled i osjećaj' neprofesionalno dizajniranih web stranica grabežljivih izdavača.

\section{Diskusija}

Rezultati studije ukratko podrazumijevaju: (1) izmišljena engleska imena, koja imaju za cilj ostaviti dojam da pozivi dolaze, kako tvrde, iz zapadnog svijeta, ili da ih preusmjeravaju (i implicitno podržavaju) zapadni naučnici; (2) oglase koji nemaju smisla zapadnom svijetu, uključujući besmislene certifikate, tvrdnje o priznavanju kvalitete časopisa izvan zapadnog svijeta; (3) nedostatak kontrole kvalitete, koji bi mogao ukazivati na to da bi kvalitetni podnesak mogao imati isti problem kao pseudonaučni članci; i (4) loš grafički jezik, što ukazuje na amatersko osoblje koje uređuje grabežljivi časopis. Sve to potvrđuje hipotezu prema kojoj grabežljivi časopis ne pripada naučnom području, a također je u stanju stajati u jezgri mogućih smjernica za razotkrivanje grabežljivih izdavača na temelju specifičnih značajki njihovih poziva. 

ruta.lasauskiene@mruni.eu more...

\title{
International Journal of Humanities and Social Science Invention
}

\author{
Call for Papers (March 2020 Issue) \\ Impact Factor 5.35 \\ Dear Author/Researcher, \\ etc. \\ ISSN (Online Version): $2319-7722$ \\ ISSN (Print): 2319 - 7714 \\ Subject Category: Humanities and Social Science. \\ IJHSSI follows the rapid publication process. \\ Publication Frequency: 12 issue per year \\ Important dates are as follows: \\ Manuscript Submission: 10th March 2020 \\ Acknowledgement Notification: within 24 hours \\ Acceptance Notification: within 10 days \\ Paper Publication: $\quad$ 20th March 2020
}

IJHSSI is peer reviewed International Journal which publishes paper online as well as print

version. IJHSSI is indexed in major indexing like EBSCO HOST, CABELL's library, ULRICH web, Jour Info etc. Papers are invited for INVENTION Journals March 2020 Issue related to all field of Humanities and Social Science

Hard copy will be dispatch within 7 days after online publication.

Please submit your paper through: pap er.indexed@rediffmail.com

Website: www.ijhssi.org

With Warm Regards

Editor-In-Chief

IJHSSI

Figure 1. Graphically unpleasant call for papers from the International Journal of Humanities and Social Science Invention.

Slika 1. Grafički neugodan poziv za radove u časopisu International Journal of Humanities and Social Science Invention.

not belong to the scientific realm, and are also able to stand at the core of possible guidelines for exposing predatory publishers based on specific features of their calls.

Unlike the previous studies examining in depth the predatory calls to look at the elements defining them (Petrişor 2016, 2017, 2018), the present study addressed the 'outlier', meaning those elements which are able to specifically distinguish the predatory journals. All the findings presented above are such distinctive features; their identification used the language criterion, which was also able to bring additional evidence for supporting the findings of previous studies (Mills and Inouye 2020) that tracked the origin of predatory publishers in the global South.

As the samples illustrate, most of the calls from the predatory publishers show that their authors are non-native English speakers. If some of the errors
Za razliku od prethodnih studija koje propituju u potpunosti grabežljive pozive gledajući elemente koji ih definiraju (Petrişor 2016, 2017, 2018), sadašnja studija se bavila 'netipičnim vrijednostima', tj. onim elementima koji mogu posebno razlikovati grabežljive časopise. Svi gore izneseni rezultati imaju izrazita obilježja; za njihovu identifikaciju korišten je kriterij jezika, koji je također mogao donijeti dodatne dokaze u prilog nalazima prethodnih studija (Mills i Inouye 2020) koje su pratile porijeklo grabežljivih izdavača s Juga.

Kao što uzorci ilustruju, većina poziva grabežljivih časopisa pokazuju da njihovi autori nisu izvorni govornici engleskog jezika. Ako su neke greške asimptomatične, uprkos njihovoj ozbiljnosti, raspona od grubih grešaka (npr. pravopisne greške, neslaganje subjekta i predikata, miješanje riječi, nedostatak poznavanja značenja riječi) do problema koje 
are asymptomatic, despite their seriousness, ranging form gross errors (e.g., misspellings, subject-verb disagreements, word confusion, lack of knowledge of the word meanings) to issues detectable only by the advanced users (lack of articles and prepositions, awkward phrasing, wrong use of verbal tenses or modes), some of the samples reveal symptomatic errors. The wrong use of capitalization, punctuation, spaces (e.g., after an opening parenthesis), visible in some of the examples (e.g., the call from the IOSR JOURNALS, presented in the thematic sample no. 2) are indications that the senders come from countries were such rules do not exist, situated in North Africa, South-East Asia and the Middle East (e.g., Chinese, Arabic), confirming the previous studies (Mills and Inouye 2020). These elements have not been mentioned in the previous literature, which pinpointed only the poor quality of English, without an in-depth analysis (Truth 2012; Bohannon 2013; Crawford 2014; Petrişor 2016).

All together, these findings offer important instruments for the detection of predatory publishers in order to avoid the deception. However, since there is no common global action against the predatory publisher despite an acute need for collaborative efforts (Moher and Moher 2016) due to the global impact, the only means of stopping the researchers being lured by the predatory publishers is to increase their awareness; in this regard, the present study makes also an important contribution. For this aim, previous studies (Petrişor 2018) suggested that libraries could play a more active role in helping the authors being deceived by the predatory journals. Libraries offer courses on writing up research, but also on the basics of the peer review process, and even issues related to what happens after the publication of a manuscript; each of these can connect to the predatory publishers, which promise a fast review and are likely to send their calls for papers to those publishing in legitimate journals. Ideally, specialized trainings should be delivered on the predatory publishing issues; some examples include the Library of Gdansk Medical University, Poland (courses and a page dedicated to the predatory publishers - https://biblioteka.gumed.edu.pl/?strona=391), University of Quebec, Montreal, Canada (page dedicated to the predatory publishers - http:// guides.bibliotheques.uqam.ca/themes/187-editeurs-predateurs?tab $=1167$ ), Library of Opole, Poland (course organized in 2019), University of Pretoria, South Africa (course organized in 2018), and Pelegrí Casanova Library of Health Sciences in Valencia, Spain (page dedicated to the predatory publishers - http://hemesalud.blogs.uv.es/revistes-depredadores/).

Although the findings make an important contribution to providing tools for detecting the predatory prepoznaju samo napredni korisnici (nedostatak članova i prijedloga, nespretne rečenice, pogrešna upotreba glagolskih vremena ili oblika), neki od uzoraka otkrivaju simptomatične greške. Pogrešna upotreba velikih slova, interpunkcije, razmaka (npr. nakon otvorene zagrade), vidljiva u nekim primjerima (npr. poziv IOSR časopisa, predstavljenog u tematskom uzorku br. 2) pokazatelji su da su pošiljatelji iz zemalja u kojima takva pravila ne postoje, a koje se nalaze u sjevernoj Africi, jugoistočnoj Aziji i na Bliskom Istoku (npr. kineski, arapski), potvrđujući prethodne studije (Mills i Inouye 2020). Ovi elementi nisu spomenuti u prethodnoj literaturi koja je ukazivala samo na lošu kvalitetu engleskog jezika, bez dublje analize (Truth 2012; Bohannon 2013; Crawford 2014; Petrişor 2016).

Svi ti rezultati zajedno nude važne instrumente za otkrivanje grabežljivih izdavača kako bi se izbjegla prevara. Međutim, budući da ne postoji zajednička globalna akcija protiv grabežljivih izdavača uprkos akutnoj potrebi za zajedničkim naporima (Moher i Moher 2016) zbog globalnog uticaja, jedini način da se spriječi da grabežljivi izdavači privuku istraživače jest porast svijesti o njima; imajući to na umu, i ova studija također daje važan doprinos. U tu svrhu, prethodne studije (Petrișor 2018) sugerisale su da biblioteke mogu igrati aktivniju ulogu u pomaganju autorima da ih ne prevare grabežljivi časopisi. Biblioteke nude kurseve za pisanje istraživanja, ali i osnove procesa recenziranja, pa čak i pitanja koja se odnose na ono što se događa nakon objavljivanja rukopisa; svaki od njih može se povezati s grabežljivim izdavačima, koji obećavaju brzi pregled i vjerojatno će poslati svoje pozive za radove onima koji objavljuju u legitimnim časopisima. U idealnom slučaju, trebalo bi održati specijalizirane obuke o problemima predatorskih izdavača; neki primjeri uključuju Biblioteku medicinskog univerziteta u Gdanjsku, Poljsku (kursevi i stranica posvećena grabežljivim izdavačima - https://biblioteka. gumed.edu.pl/?strona=391), Universitet u Quebecu, Montreal, Kanada (stranica posvećena grabežljivim izdavačima - http:/guides.bibliotheques.uqam.ca/ themes/187-editeurs-predateurs?tab=1167), Biblioteku u Opoleu, Poljska (kurs organizovan 2019), Universitet u Pretoriji, Južna Afrika (kurs organizovan 2018) i Pelegrí Casanova biblioteku zdravstvenih nauka u Valenciji, Španija (stranica posvećena grabežljivim izdavačima - http://hemesalud.blogs. uv.es/revistes-depredadores/).

Iako rezultati značajno doprinose pružanju alata za otkrivanje grabežljivih poziva i podršku istraživačima, njihova metodologija ograničena je na empirijsku i individualnu analizu nekoliko 'ekstremnih' poziva. Iako je metoda dobra za razaznavanje elemenata koji bi promakli ako pokušate analizirati više poziva koristeći - ako je opseg posla prevelik 
calls and supporting the researchers, its methodology is limited to the empirical and individual analysis of few 'extreme' calls. Although the method is good for discerning elements that would escape if trying to analyze more calls, using - if the volume of work is too large for individual analyses - automated procedures (Markowitz et al. 2020), each method has its own advantage; the automated procedures are, by processing large volumes of data, able to detect patterns and trends unable to be seen if the calls were analyzed one by one, have the advantage of reproducibility, and are less affected by individual biases. For this reason, an important direction for the future research would be to use a join approach, combining individual analyses with automated procedures, and joining the advantages of the two methodologies.

\section{Conclusions}

This research was aimed to analyze the predatory calls looking for the 'outliers', which are language elements able to distinguish precisely the predatory publishers. The findings, included invented English names, advertisements making no sense for the Western world, lack of quality control and a poor graphic language, confirm the hypothesis according to which the predatory publishers are located in countries where English is not commonly spoken, and provide additional evidence for their location in the 'global South'. At the same time, these distinctive features are likely to support researchers into being deceived. In the process of increasing their awareness, the libraries can play a key role. From a methodological perspective, the study suggests a need for developing more and deeper analyses of the call for papers, using a joint approach combining automated procedures with thorough examinations of each individual call. za pojedinačne analize - automatizirane postupke (Markowitz et al. 2020), svaka metoda ima svoju prednost; automatizirani postupci obradom velike količine podataka mogu otkriti obrasce i trendove koji se ne mogu vidjeti ako se pozivi analiziraju jedan po jedan, imaju prednost ponovljivosti i na njih manje utiču lične pristranosti. Iz tog razloga, važan smjer za buduća istraživanja bio bi korištenje zajedničkog pristupa, kombiniranje individualnih analiza $\mathrm{s}$ automatiziranim postupcima i spajanje prednosti dviju metodologija.

\section{Zaključak}

Ovo je istraživanje imalo za cilj analizirati grabežljive pozive u potrazi za 'netipičnim vrijednostima', tj. jezičkim elementima koji mogu precizno razlikovati grabežljive izdavače. Rezultati, uključujući izmišljena engleska imena, oglase koji nemaju smisla za zapadni svijet, nedostatak kontrole kvalitete i loš grafički jezik, potvrđuju hipotezu prema kojoj se grabežljivi izdavači nalaze u zemljama u kojima se engleskim jezikom najčešće ne govori i koje pružaju dodatne dokaze o njihovoj lokaciji na Jugu. Istovremeno, ove distinktivne odlike će vjerojatno pomoći da istraživači budu prevareni. U procesu povećanja njihove svijesti, biblioteke mogu odigrati ključnu ulogu. Iz metodološke perspektive, studija sugeriše potrebu za razvijanjem dubljih analiza poziva za slanje radova, koristeći zajednički pristup koji kombinira automatizirane postupke $\mathrm{s}$ temeljitim ispitivanjem svakog pojedinog poziva. 


\section{Sources / Izvori}

Alnajjar, Hend, U. Asif, N. Bano, and W. Aljohani. 2020. "Faculty Experiences with Predatory Conferences: A Qualitative Study" La Prensa Medica Argentina S2: 025. DOI: https://doi. org/10.47275/0032-745X-S2-025.

Bell, Kirsten. 2017. “'Predatory' Open Access Journals as Parody: Exposing the Limitations of 'Legitimate' Academic Publishing" tripleC 15(2): 651-662. DOI: https://doi. org/10.31269/triplec.v15i2.870.

Bohannon, John. 2013. "Who's afraid of peer review?" Science 342 (6154): 60-65. DOI: https://doi.org/10.1126/science.342.6154.60.

Butler, Declan. 2013. "The Dark Side of Publishing” Nature 495 (7442): 433-435. DOI: https://doi.org/10.1038/495433a

Chambers, Alan H. 2019. "How I became easy prey to a predatory publisher" Science, May 9, 2019. DOI: https://doi.org/10.1126/science. caredit.aax 9725.

Crawford, Walt. 2014. "Journals, 'Journals' and Wannabes: Investigating the List." Cites \& Insights 14 (7): 1-45.

Cukier, Samantha, Manoj Lalu, Gregory L. Bryson, Kelly D. Cobey, Agnes Grudniewicz, and David Moher. 2020. "Defining predatory journals and responding to the threat they pose: a modified Delphi consensus process" British Medical Journal Open 10: e035561. DOI: https://doi.org/https://doi.org/10.1136/ bmjopen-2019-035561.

Dadkhah, Mehdi, Glenn Borchardt, and Tomasz Maliszewski. 2017. "Fraud in Academic Publishing: Researchers Under Cyber-Attacks" The American Journal of Medicine 130 (1): 27-30. DOI: http://dx.doi.org/10.1016/j.amjmed.2016.08.030.

Dizdar, Srebren. 2019. "Za i protiv otvorenog pristupa akademskim djelima u kontekstu savremenog istraživačko-izdavačkog procesa" Bosniaca 24: 26-38. DOI: http://doi. org/10.37083/bosn.2019.24.26.

Djuric, Dragan. 2015. "Penetrating the omerta of predatory publishing: the Romanian connection" Science and Engineering Ethics 21 (1): 183-202. DOI: http://doi.org/10.1007/ s11948-014-9521-4.

Ebadi, Saman, and Gerranaz Zamani. 2018. "Predatory publishing as a case of symbolic violence: A critical English for academic purposes approach" Cogent Education 5: 1501889. DOI: https://doi.org/10.1080/2331 186X.2018.1501889.

Grudniewicz, Agnes, David Moher, Kelly D. Co- bey, Gregory L. Bryson, Samantha Cukier, Kristiann Allen, Clare Ardern, Lesley Balcom, Tiago Barros, Monica Berger, Jairo Buitrago Ciro, Lucia Cugusi, Michael R. Donaldson, Matthias Egger, Ian D. Graham, Matt Hodgkinson, Karim M. Khan, Mahlubi Mabizela, Andrea Manca, Katrin Milzow, Johann Mouton, Marvelous Muchenje, Tom Olijhoek, Alexander Ommaya, Bhushan Patwardhan, Deborah Poff, Laurie Proulx, Marc Rodger, Anna Severin, Michaela Strinzel, Mauro Sylos-Labini, Robin Tamblyn, Martie van Niekerk, Jelte M. Wicherts, and Manoj M. Lalu. 2019. "Predatory journals: no definition, no defence" Nature 576 (7786): 210212. DOI: https://doi.org/10.1038/d41586019-03759-y.

Habibzadeh, Farrokh, and Ana-Maria Simundic. 2017. "Predatory journals and their effects on scientific research community" Biochemia Medica 27 (2): 270-272. DOI: http://doi.org/ 10.11613/BM.2017.028.

Hossain, Md. Sajjad. 2020. "Predatory journals: The underlying strategies" American Journal of Research 5-6: 62-73.

Kurt, Serhat. 2018. "Why do authors publish in predatory journals?" Learned Publishing 31: 141-147. DOI: https://doi.org/10.1002/ leap. 1150.

Markowitz, David Matthew, Jill H. Powell, and Jeffrey T. Hancock. 2020. "The Writing Style of Predatory Publishers" Presented at 2014 ASEE Annual Conference \& Exposition. Paper no. 8614. https://www.asee.org/public/ conferences/32/papers/8614/view.

Mills, David, and K. Inouye. 2020. "Problematizing 'predatory publishing': A systematic review of factors shaping publishing motives, decisions, and experiences" Learned Publishing. DOI: https://doi.org/10.1002/leap.1325.

Moher, David, and Ester Moher. 2016. "Stop Predatory Publishers Now: Act Collaboratively" Annals of Internal Medicine 164 (9): 616-618. DOI: https://doi.org/10.7326/M15-3015.

Moher, David, Larissa Shamseer, Kelly D. Cobey, Manoj M. Lalu, James Galipeau, Marc T. Avey, Nadera Ahmadzain, Mostafa Alabousi, Pauline Barbeau, Andrew Beck, Raymond Daniel, Robert Frank, Mona Ghannad, Candyce Hamel, Mona Hersi, Brian Hutton, Inga Isupov, Trevor A. McGrath, Matthew D. F. McInnes, Matthew J. Page, Misty Pratt, Kusala Pussegoda, Beverley Shea, Anubhav Srivastava, Adrienne Stevens, Kednapa Thavorn, Sasha van Katwyk, Roxanne Ward, Dianna Wolfe, Fatemeh Yazdi, Ash- 
ley M. Yu, and Hedyeh Ziai. 2017. "Stop this waste of people, animals and money" Nature 549 (7670): 23-25. DOI: https://doi. org/10.1038/549023a.

Paris, Thomas, Harry Kim, B'Elanna Torres, Kes Ocampa, Kathryn Janeway, and Lewis Zimmerman. 2017. "Rapid genetic and developmental morphological change following extreme celerity" American Research Journal of Biosciences 3: 1-3.

Petrişor, Alexandru-Ionuţ. 2016. "Evolving strategies of the predatory journals" Malaysian Journal of Library and Information Science 21 (1): 1-17. DOI: http://doi.org/10.22452/ mjlis.vol21no1.1.

Petrişor, Alexandru-Ionuţ. 2017. "Are the predatory publishers collapsing or re-inventing themselves?" Library and Information Science Research Electronic Journal 27 (2): 71-79. DOI: https://www.libres-ejournal.info/2570/.

Petrişor, Alexandru-Ionuţ. 2018. "Predatory Publishers using Spamming Strategies for Call for Papers and Review Requests: A Case Study" Desidoc Journal of Library \& Information Technology 38 (3): 199-207. DOI: http://doi.org/10.14429/djlit.38.3.12551.

Petrişor, Alexandru-Ionuţ. 2020. "Peer Review under the Ethical Lens: Possible Questions" Bosniaca 25: 183-197. DOI: http://doi. org/10.37083/bosn.2020.25.183.

Shaghaei, Najmeh, Charlotte Wien, Jakob Povl Holck, Anita L. Thiesen, Ole Ellegaard, Evgenios Vlachos, and Thea Marie Drachen. 2018. "Being a Deliberate Prey of a 'Predator-Researchers' Thoughts after Having Published in a Predatory Journal" Liber Quarterly 28 (1): 1-17. DOI: http://doi.org/http://doi. org/10.18352/lq. 1025 .
Soler, Josep, and Andrew Cooper. 2019. "Unexpected Emails to Submit Your Work: Spam or Legitimate Offers? The Implications for Novice English L2 Writers" Publications 7: 7. DOI: http://doi.org/10.3390/publications7010007.

Sorokowski, Piotr, Emanuel Kulczycki, Agnieszka Sorokowska, and Katarzyna Pisanski. 2017. "Predatory journals recruit fake editor" $\mathrm{Na}$ ture 543 (7646): 481-483. DOI: http://doi. org/10.1038/543481a.

Teixeira da Silva, Jaime A. 2017. “Jeffrey Beall's 'predatory' lists must not be used: they are biased, flawed, opaque and inaccurate" Bibliothecae.It 6 (1): 425-436. DOI: https://doi. org/10.6092/issn.2283-9364/7044.

Truth, Frank. 2012. "Pay Big to Publish Fast: Academic Journal Rackets" Journal for Critical Education Policy Studies 10 (2): 55-105.

Watson, Roger. 2017. "Beall's list of predatory open access journals: RIP” Nursing Open 4 (2): 60. DOI: https://doi.org/10.1002/nop2.78.

Xia, Jingfeng and Megan P. Smith. 2018. "Alternative journal impact factors in open access publishing" Learned Publishing 31 (4): 403-411. DOI: https://doi.org/10.1002/leap.1200. 